\title{
Rapid HPLC Method for Determination of Rebaudioside D in Leaves of Stevia rebaudiana Bertoni Grown in the Southeast of México
}

\author{
Irma Aranda-González1, Yolanda Moguel-Ordoñez ${ }^{2}$, David Betancur-Ancona1 ${ }^{*}$ \\ ${ }^{1}$ Facultad de Ingeniería Química, Universidad Autónoma de Yucatán, Mérida, México \\ ${ }^{2}$ Instituto Nacional de Investigaciones Forestales, Agrícolas y Pecuarias (INIFAP), Mocochá, México \\ Email: $\underline{\text { bancona@uady.mx }}$
}

Received 4 July 2014; revised 19 August 2014; accepted 2 September 2014

Copyright (C) 2014 by authors and Scientific Research Publishing Inc.

This work is licensed under the Creative Commons Attribution International License (CC BY). http://creativecommons.org/licenses/by/4.0/

\section{Abstract}

Stevia leaves contain glycosides on which biological activity and sweetening capacity has been reported. Besides the main glycosides-stevioside and rebaudioside $A$-there are minor glycosides that may contribute to the activity and thus it is important to quantify them. Rebaudioside $D$ is one of the minor glycoside present in $S$. rebaudiana leaves and there are no reports of a validated method to quantify it. Therefore a simple and sensitive high performance liquid chromatography (HPLC) method was validated for the determination of rebaudioside D in leaves of Stevia rebaudiana B. grown in the southeast of México. HPLC method was performed using a C18 column $(250 \mathrm{~mm} \times 4.6 \mathrm{~mm}, 5 \mu \mathrm{m})$ and $\mathrm{UV}$ detector set at $210 \mathrm{~nm}$. The mobile phase consisted of 32:68 (v/v) mixture of acetonitrile and sodium phosphate buffer $(10 \mathrm{mmol} / \mathrm{L}, \mathrm{pH} 2.6)$, set to a flow rate of $1.0 \mathrm{ml} / \mathrm{min}$. The calculated parameters were: sensitivity, linearity, limit of detection (LOD), limit of quantification (LOQ), accuracy and precision. The retention time of rebaudioside $D$ was found to be $3.47 \mathrm{~min} \pm 0.04$ (S.D.). The calibration curves were linear over the working range $(25-150 \mu \mathrm{g} / \mathrm{ml})$, with correlation coefficient $\geq 0.99$ and determination coefficient $\geq 0.98$. The calculated limit of detection (LOD) was $8.53 \mu \mathrm{g} / \mathrm{ml}$, while the limit of quantitation (LOQ) was $25.85 \mu \mathrm{g} / \mathrm{ml}$. The percent recoveries of fortified samples were $100 \% \pm 10 \%$ and precision relative standard deviation was $\leq 2.79 \%$. The criteria of validation showed accuracy, linearity, and precision; therefore the method is suitable for quantitative analysis of rebaudioside $D$ in Stevia rebaudiana leaves. Rebaudioside D content $(\mathrm{g} / \mathbf{1 0 0 g})$ in Morita II and Criolla varieties grown in the southeast of Mexico were 0.43 and 0.46 , respectively with no significant differences $(p>0.05)$ between them.

${ }^{*}$ Corresponding author.

How to cite this paper: Aranda-González, I., Moguel-Ordoñez, Y. and Betancur-Ancona, D. (2014) Rapid HPLC Method for Determination of Rebaudioside D in Leaves of Stevia rebaudiana Bertoni Grown in the Southeast of México. American Journal of Analytical Chemistry, 5, 813-819. http://dx.doi.org/10.4236/ajac.2014.513090 


\section{Keywords}

\section{Rebaudioside D, Stevia Rebaudiana, HPLC, Validation}

\section{Introduction}

Stevia is a genus of plant in the Asteraceae family, which is native to subtropical and tropical regions of South America and Central America. Stevia rebaudiana Bertoni is a perennial shrub that grows 65 to $80 \mathrm{~cm}$ in height and within species of Stevia it has the highest potential sweetener and is known as ka'ahe'e ("sweet herb") in Guarani [1]. The major constituents in the leaves of $S$. rebaudiana are the potently sweet glycosides namely stevioside, rebaudioside A, C and D, and dulcoside A. These compounds are glycosides derivatives of steviol diterpene (ent-13-hydroxykaur-16-en-19-oic acid), which are formed by replacing the hydrogen atom of carboxyl with glucose, xylose and rhamnose forming an ether [2]. Steviol has two hydroxyl groups, one attached to carbon 19 (C-19) and the other one attached to carbon 13 (C-13) (Figure 1), which can be glycosylated and form various derivative compounds generally known as steviol glycosides (Table 1). In cultivated varieties usually the main steviol glycosides compounds are four: stevioside, rebaudioside $\mathrm{A}$, rebaudioside $\mathrm{C}$ and dulcoside. In small quantities, rebaudioside D $(<0.4 \%)$ along with rebaudioside C $(1 \%-2 \%)$, dulcoside A $(0.4 \%-0.7 \%)$, esteviolbioside, rubusoside, rebaudioside B, E and F $(<0.4 \%$ each) can be found [1] [3] [4].

Besides the sweetness of Stevia rebaudiana, there are important biological properties that have been identified, such as anti-cariogenic capacity [5], antineoplastic [6], antihyperglycemic [7], antihypertensive [8] and anti-inflammatory activity [9].

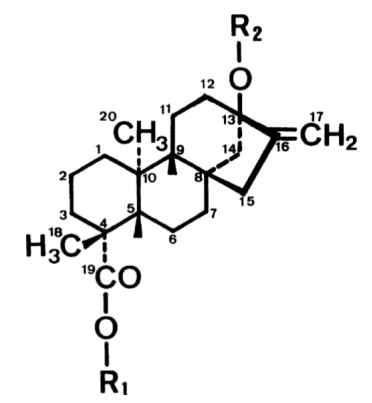

Figure 1. Chemical structure of the aglycone of steviol glycosides.

Table 1. Structure, formula and molecular weight of derived steviol glycosides.

\begin{tabular}{cccc}
\hline & & Characteristics & Molecular weight \\
\cline { 2 - 4 } Compound & $\mathbf{R}_{\mathbf{1}}$ & $\mathbf{R}_{\mathbf{2}}$ & 804.88 \\
Stevioside & $\beta$-Glc & $\beta$-Glc- $\beta$-Glc $(2 \rightarrow 1)$ & 967.01 \\
Rebaudioside A & $\beta$-Glc & $\beta$-Glc- $\beta$-Glc $(2 \rightarrow 1) \downarrow \beta$-Glc $(3 \rightarrow 1)$ & 804.87 \\
Rebaudioside B & $\mathrm{H}$ & $\beta$-Glc- $\beta$-Glc $(2 \rightarrow 1) \downarrow \beta$-Glc $(3 \rightarrow 1)$ & 951.03 \\
Rebaudioside C & $\beta$-Glc & $\beta$-Glc- $\alpha$-Rha( $(2 \rightarrow 1) \downarrow \beta$-Glc $(3 \rightarrow 1)$ & 1129.17 \\
Rebaudioside D & $\beta$-Glc- $\beta$-Glc $(2 \rightarrow 1)$ & $\beta$-Glc- $\beta$-Glc $(2 \rightarrow 1) \downarrow \beta$-Glc $(3 \rightarrow 1)$ & 966.43 \\
Rebaudioside E & $\beta$-Glc- $\beta$-Glc $(2 \rightarrow 1)$ & $\beta$-Glc- $\beta$-Glc $(2 \rightarrow 1)$ & 936.98 \\
Rebaudioside F & $\beta$-Glc & $\beta$-Glc- $\beta$-Xyl $(2 \rightarrow 1) \downarrow \beta$-Glc $(3 \rightarrow 1)$ & 788.87 \\
Dulcoside A & $\beta$-Glc & $\beta$-Glc- $\alpha$-Rha $(2 \rightarrow 1)$ & 642.7316 \\
Rubososide & $\beta$-Glc & $\beta$-Glc & 642.73 \\
Steviolbioside & $\mathrm{H}$ & $\beta$-Glc- $\beta$-Glc $(2 \rightarrow 1)$ & \\
\hline
\end{tabular}

Glc: glucose, Rha: rhamnose and Xyl: xylose. 
Different analytical techniques have been reported for determination of steviol glycosides in S. rebaudiana. These include capillary electrophoresis [10] [11], LC/mass spectrometry [12], Electrospray ionization mass spectrometry (ESI-MS) [3], Infrared Spectroscopy [10] [13], and high-performance liquid chromatography (HPLC) [4] [14]-[18] and high-performance thin layer chromatography (HPTLC) [19]-[21] among others.

However, one of simplest and most reliable method is HPLC and hence in 2010, the FAO/WHO Joint Expert Committee on Food Additives (JECFA) in the 73rd meeting recommended an HPLC method for determination of steviol glycosides [22]. However the existing analytical methods are mainly focused on the quantification of either rebaudioside A or stevioside and to a lesser extent minor glycosides, such as rebaudioside $\mathrm{D}$ also present in the extracts of the leaves which may contribute to sweetness or biological activity and on which there are no reports of its contents in S. rebaudiana cultivated in Mexico. Therefore, the aim of this study was to modify and validate the proposed JECFA method for the quantification of Rebaudioside D contained in Stevia rebaudiana Bertoni leaves grown in the Southeast of Mexico.

\section{Materials and Methods}

\subsection{Chemical and Reagents}

Standard of rebaudioside D (ASB-00018229) was purchased from Chromadex (Irvine, CA) whereas acetonitrile and water (HPLC grade) were purchased from J.T. Baker (Phillipsburg, NJ). Glycoside standard was lyophilized under vacuum pressure of $133 \times 10^{-3} \mathrm{Bar}$ and a temperature of $-40^{\circ} \mathrm{C}$ (Labconco, Kansas City, MO), then mixed with HPLC water, filtered through $0.45 \mu \mathrm{m}$ and stored at $-20^{\circ} \mathrm{C}$ prior to use.

\subsection{Instrumentation and Chromatographic Conditions}

Accordingly with JEFCA method [22], liquid chromatography under isocratic conditions was performed using an Agilent 100 HPLC system with UV-Vis detector set to a wavelength of $210 \mathrm{~nm}$. Separation was carried out on Luna C18 (2) (length: $250 \mathrm{~mm}$; inner diameter: $4.6 \mathrm{~mm}$, particle size: $5 \mu \mathrm{m}$ ) column (Phenomenex Co., Ltd., CA, USA) without temperature control. The mobile phase consisted of 32:68 mixture of acetonitrile and 10 $\mathrm{mmol} / \mathrm{L}$ sodium phosphate buffer ( $\mathrm{pH}$ 2.6) used at a constant flow rate of $1 \mathrm{ml} / \mathrm{min}$. Chromatographic analysis was performed with Clarity software 2.7.3.498 version (2009). The sample injection volume was $20 \mu \mathrm{L}$.

\subsection{Stevia rebaudiana Extract}

The leaves of two varieties of S. rebaudiana, Morita II and Criolla, were collected from the Southeast of Mexico. Dried material was powdered and kept in the dark until analysis. For preparing extracts, $0.5 \mathrm{~g}$ of powdered leaves were weighed and extracted three times with water with $5 \mathrm{ml}$ each time in a boiling water bath at $100^{\circ} \mathrm{C}$ for $30 \mathrm{~min}$. Extracts were cooled to room temperature and centrifuged for 10 minutes $\left(2500 \times \mathrm{g}, 10^{\circ} \mathrm{C}\right)$ to facilitate separation of the aqueous phases of the leaves. The aqueous phases were transferred to a $25 \mathrm{ml}$ volumetric flask and filled to capacity after the last extraction. The solution was filtered through a membrane filter $(0.45 \mu \mathrm{m})$ to remove any solid residue before HPLC analysis [4].

\subsection{Method Validation}

In agreement with ICH guidelines [23], the quality, reliability and consistency of the validated method were determined based on sensitivity, linearity, limit of detection (LOD), limit of quantification (LOQ), accuracy and, precision. According to ICH guidelines [23], each parameter was defined as follows: Sensitivity is the change in the response of a measuring instrument divided by the corresponding change in the stimulus, linearity is the ability of the method (within a given range) to obtain results that are directly proportional to the concentration (amount) of analyte, limit of detection (LOD) is the lowest concentration of an analyte in a sample that can be detected but not necessarily quantitated as an exact value, limit of quantification (LOQ) is the lowest concentration of an analyte contained in a sample that can be quantitatively determined, accuracy is the closeness of agreement between the value which is accepted either as a conventional true value or an accepted reference value and the value found, and precision is the closeness of agreement between a series of measurements obtained from multiple samples of a homogeneous sample under the prescribed conditions. 


\subsection{Statistics}

Statistical analyzes were performed using Statgraphics to evaluate the linearity of the system; the confidence intervals of the intercept in $y$ and confidence intervals of the slope were calculated using the GraphPad Prism program version 5.00. Microsoft Office Excel was used for analysis of limit of quantification, limit of detection, accuracy and precision.

\section{Results and Discussion}

\subsection{Sensitivity, Linearity, LOD and LOQ}

In agreement with ICH guidelines [23] the parameters were operationalized as: Sensitivity is the slope of the calibration function. Linearity was calculated with the evaluation of 6 concentrations of the standards in a concentration range of 25 - $150 \mu \mathrm{g} / \mathrm{ml}$; to evaluate the linearity, a graph of the signal produced as a function of analyte concentration and the linear regression by the method of least squares was calculated (Figure 2). Also, the correlation coefficient and the intercept on $y$ were calculated. Limit of detection (LOD) was determined using the formula: LOD = 3.3 (Standard Deviation of intercept)/slope (S). Limit of quantification (LOQ) was determined using the formula LOQ $=10$ (Standard Deviation of intercept)/slope (S).

As seen in Table 2, the parameters of simple linear regression were calculated for rebaudioside D at concentrations of 25 - $150 \mu \mathrm{g} / \mathrm{ml}$. Since the correlation coefficients of the standard curves were greater than 0.99 , while the coefficients of determination were $\geq 0.98 \%$, it can be concluded that the analytical methodology used

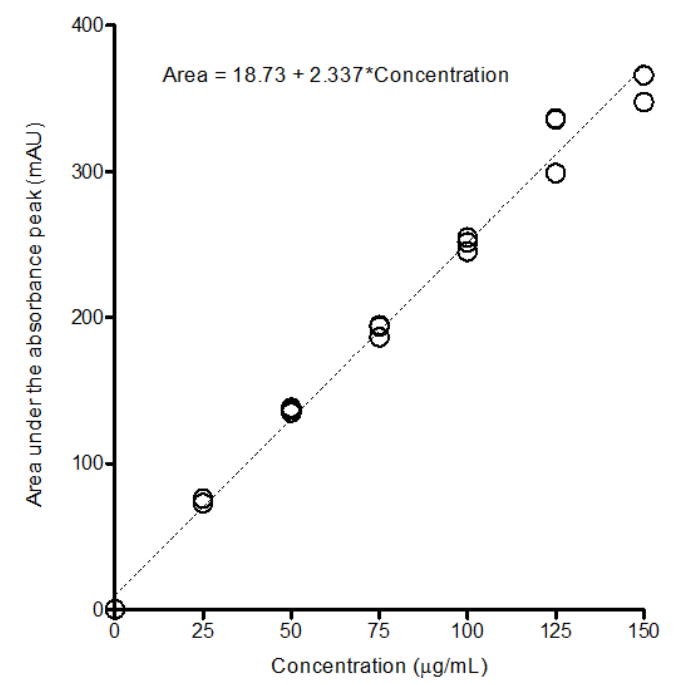

Figure 2. Linear regression of Rebaudioside D standard under chromatographic conditions. Data represents the area under the absorbance peaks for each concentration of Rebaudioside D (blank circles) and linear regression analysis calculated by the method of least squares (dotted line).

Table 2. Parameters calculated from linear regression model peak area vs. concentration $(\mathrm{y}=\mathrm{a}$ $+\mathrm{b}^{*} \mathrm{x}$ ) of Rebaudioside D.

\begin{tabular}{cc}
\hline Parameters & Value \\
\hline Coefficient of correlation $(\mathrm{r})$ & 0.993 \\
Coefficient of determination $\left(\mathrm{R}^{2}\right)$ & 0.988 \\
$y$-intercept & 18.73 \\
CI of $y$-Intercept & 5.92 to 31.54 \\
Slope (sensitivity) & 2.337 \\
CI of slope & 2.20 to 2.46 \\
LOD $(\mu \mathrm{g} / \mathrm{ml})$ & 8.53 \\
LOQ $(\mu \mathrm{g} / \mathrm{ml})$ & 25.85 \\
\hline
\end{tabular}

CI: confidence interval at 95\%; LOD: limit of detection [3.3 (Standard deviation of intercept)/slope (S)]; LOQ: limit of quantification [10 (Standard deviation of intercept)/slope (S)]. 
was linear over the concentration range studied and therefore the model is suitable for quantifying the content of glycosides.

\subsection{Precision and Accuracy}

In accordance with ICH guidelines [23], accuracy was evaluated by performing recovery studies of fortified samples; recoveries were determined by adding $25 \mu \mathrm{g} / \mathrm{ml}$ of rebaudioside D to three samples of $S$. rebaudiana extract previously quantified; the recovery of each analyte was expressed as percentage and calculated by the equation Recovery $(\%)=\mathrm{S} 1 /(\mathrm{S} 2+\mathrm{S} 3) \times 100$; where $\mathrm{S} 1=$ amount found $(\mu \mathrm{g} / \mathrm{ml})$ in the spiked sample, $S 2=$ amount present originally in the unfortified sample, and $S 3=$ amount $(\mu \mathrm{g} / \mathrm{ml})$ of analyte added to the sample. Repeatability and intermediate precision were evaluated and expressed as relative standard deviation (\% RSD); for this purpose, three samples of rebaudioside D were analyzed using the chromatographic condition described previously in the same day (intra-day precision) or a different day (inter-day precision).

The recovery experiment with the spiked samples, conducted in triplicate, demonstrated a good recovery of 96.17\% for Morita II and 99\% for Criolla variety. To date, no studies evaluating the accuracy in quantifying Rebaudioside D with the same method have been reported, since most of the published studies are about rebaudioside A or stevioside. However, the recovery rate found for rebaudioside D is in the range that has been reported for rebaudioside A (93\% - 108\%) or stevioside (95.7\% - 106\%) [4] [19] [24] in different chromatographic methods and therefore considered acceptable.

Repeatability or intra-day precision was evaluated by analyzing relative standard deviation (RSD) for area under the peak and also for retention time through the run. Percent of RSD for all concentration were $\leq 2.44 \%$ and $\leq 2.60 \%$, for area and retention time, respectively (Table 3 ). The average retention time was $3.47 \mathrm{~min}$. Intermediate or inter-day precision was found by repeating the same procedure, although 6 days later. The precision for retention time was $\leq 0.79 \%$ RSD in all cases, whereas the relative standard deviation for peak area was $\leq 2.79 \%$ (Table 3 ). In this regard, the \% RSD of peak area found is slightly higher than those reported for the major glycosides Rebaudioside A (0.70\%) and stevioside (0.41\%) using a similar chromatographic method [18], but less than $10 \%$ which is the value generally regarded as appropriate and therefore it can be considered that this method is precise to quantify rebaudioside $\mathrm{D}$.

\subsection{Application of the Analytical Method in Determination of Rebaudioside D in S. rebaudiana Leaves}

After the validation of the method, extracts of S. rebaudiana Bertoni Morita II and Criolla varieties were analyzed to quantify rebaudioside D present in both. Each sample was analyzed in triplicate and the concentration calculated through the equation of linear regression constructed with standard. The content of rebaudioside $\mathrm{D}$ in Criolla variety is $0.46 \pm 0.00$, while in the Morita II variety is $0.43 \pm 0.02$ (g/100g of dry leaf), without significant differences between them ( $p>0.05$ by student's t-test). It has been reported a matrix load visible in the beginning of the extract chromatograms within 5 minutes, which may be caused by proteins, resins, organic acids, pigments, etc. [14]. These components may decrease the life of the column and therefore it has been described the use of guard column in the HPLC equipment or a previous analytical method such as SPE extraction [25] to remove these impurities. However, although the pre-treatment is useful and improves the chromatographic profile, it is not essential for the identification and quantification of rebaudioside D (Figure 3). To date, there are no

Table 3. Intra-day and inter-day precision of Rebaudioside D.

\begin{tabular}{|c|c|c|c|c|c|}
\hline Precision & $\begin{array}{c}\text { Concentration } \\
(\mu \mathrm{g} / \mathrm{ml})\end{array}$ & $\begin{array}{l}\text { Retention Time } \\
\text { (Mean } \pm \text { SD) }\end{array}$ & $\begin{array}{c}\text { \% RSD } \\
\text { Time }\end{array}$ & $\begin{array}{c}\text { Peak Area } \\
(\text { Mean } \pm \text { SD) }\end{array}$ & \% RSD Area \\
\hline \multirow{3}{*}{ Intra-day precision } & 25 & $3.39 \pm 0.09$ & 2.60 & $111.42 \pm 2.71$ & 2.44 \\
\hline & 75 & $3.48 \pm 0.01$ & 0.37 & $291.05 \pm 6.67$ & 2.29 \\
\hline & 150 & $3.46 \pm 0.02$ & 0.55 & $487.57 \pm 8.83$ & 1.81 \\
\hline \multirow{3}{*}{ Inter-day precision } & 25 & $3.49 \pm 0.02$ & 0.46 & $619.04 \pm 3.32$ & 0.54 \\
\hline & 75 & $3.50 \pm 0.02$ & 0.61 & $594.08 \pm 11.36$ & 1.91 \\
\hline & 150 & $3.50 \pm 0.03$ & 0.79 & $714.06 \pm 19.31$ & 2.79 \\
\hline
\end{tabular}

\% RSD: Relative standard deviation 


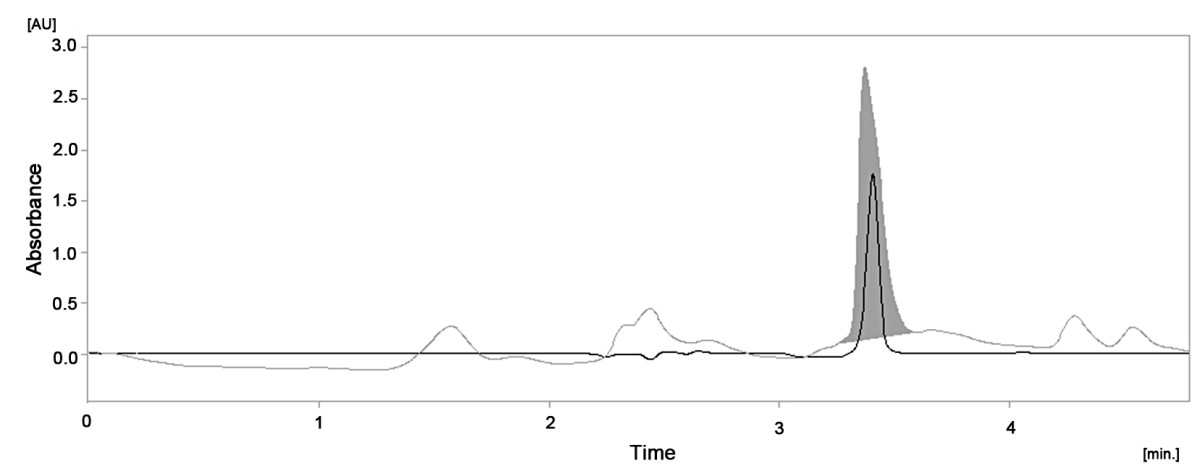

Figure 3. Typical overlay chromatogram of Rebaudioside D standard (black line) and S. rebaudiana extract (grey line) without guard column.

reports of the content of Rebaudioside D in Stevia rebaudiana varieties grown in the Yucatan Peninsula, and the amount found in this study is slightly higher than previously reported in the international literature of $<0.4 \%$ [4]. This may be due to the amount of rainfall and the solar radiation that is known to increase the content of glycosides [26].

\section{Conclusion}

HPLC method was validated for determination and quantification of rebaudioside D. The method validation showed accuracy $(96.17 \%$ - 99\%), linearity $(\mathrm{R}=0.99)$, and precision $(\leq 2.79 \% \mathrm{RSD})$; therefore it can be applied for quantitative analysis of minor steviol glycosides in Stevia rebaudiana leaves. The content of rebaudioside D in two varieties of Stevia rebaudiana grown in the Southeast of Mexico was in the range of $0.43-0.46$ (g/100g of dry leaf), without significant differences between them.

\section{Acknowledgements}

This work was supported by Fondos Fiscales-INIFAP through projects named "Desarrollo de productos alimenticios elaborados con hoja de Stevia rebaudiana Bertoni”. Also, I.A.G. received a CONACYT’s scholarship during postgraduate studies.

\section{References}

[1] Goyal, S.K., Samsher and Goyal, R.K. (2009) Stevia (Stevia rebaudiana) a Bio-Sweetener: A Review. International Journal of Food Sciences and Nutrition, 61, 1-10. http://dx.doi.org/10.3109/09637480903193049

[2] Chaturvedula, V.S., Upreti, M. and Prakash, I. (2011) Diterpene Glycosides from Stevia rebaudiana. Molecules, 16, 3552-3562. http://dx.doi.org/10.3390/molecules16053552

[3] Jackson, A.U., Tata, A., Wu, C., Perry, R.H., Haas, G., West, L. and Cooks, R.G. (2009) Direct Analysis of Stevia Leaves for Diterpene Glycosides by Desorption Electrospray Ionization Mass Spectrometry. Analyst, 134, 867-874. http://dx.doi.org/10.1039/b823511b

[4] Woelwer-Rieck, U., Lankes, C., Wawrzun, A. and Wüst, M. (2010) Improved HPLC Method for Evaluation of the Major Steviol Glycosides in Leaves of Stevia rebaudiana. European Food Research and Technology, 231, 581-588. http://dx.doi.org/10.1007/s00217-010-1309-4

[5] Das, S., Das, A.K., Murphy, R.A., Punwani, I.C., Nasution, M.P. and Kinghorn, A.D. (1992) Evaluation of the Cariogenic Potential of the Intense Natural Sweeteners Stevioside and Rebaudioside A. Caries Research, 26, 363-366. http://dx.doi.org/10.1159/000261469

[6] Mizushina, Y., Akihisa, T., Ukiya, M., Hamasaki, Y., Murakami-Nakai, C., Kuriyama, I., Takeuchi, T., Sugawara, F. and Yoshida, H. (2005) Structural Analysis of Isosteviol and Related Compounds as DNA Polymerase and DNA Topoisomerase Inhibitors. Life Sciences, 77, 2127-2140. http://dx.doi.org/10.1016/j.lfs.2005.03.022

[7] Jeppesen, P.B., Gregersen, S., Alstrup, K.K. and Hermansen, K. (2002) Stevioside Induces Antihyperglycaemic, Insulinotropic and Glucagonostatic Effects in Vivo: Studies in the Diabetic Goto-Kakizaki (GK) Rats. Phytomedicine, 9, 9-14. http://dx.doi.org/10.1078/0944-7113-00081

[8] Chan, P., Tomlinson, B., Chen, Y.J., Liu, J.C., Hsieh, M.H. and Cheng, J.T. (2000) A Double-Blind Placebo-Con- 
trolled Study of the Effectiveness and Tolerability of Oral Stevioside in Human Hypertension. British Journal of Clinical Pharmacology, 50, 215-220. http://dx.doi.org/10.1046/j.1365-2125.2000.00260.x

[9] Yasukawa, K., Kitanaka, S. and Seo, S. (2002) Inhibitory Effect of Stevioside on Tumor Promotion by 12-O-Tetradecanoylphorbol-13-Acetate in Two-Stage Carcinogenesis in Mouse Skin. Biological \& Pharmaceutical Bulletin, 25, 1488-1490. http://dx.doi.org/10.1248/bpb.25.1488

[10] Dacome, A., Da Silva, C., Da Costa, C., Fontana, J., Adelmann, J. and Da Costa, S. (2005) Sweet Diterpenic Glycosides Balance of a New Cultivar of Stevia rebaudiana (Bert.) Bertoni: Isolation and Quantitative Distribution by Chromatographic, Spectroscopic, and Electrophoretic Methods. Process Biochemistry, 40, 3587-3594. http://dx.doi.org/10.1016/j.procbio.2005.03.035

[11] Mauri, P., Catalano, G., Gardana, C. and Pietta, P. (1996) Analysis of Stevia Glycosides by Capillary Electrophoresis. Electrophoresis, 17, 367-371. http://dx.doi.org/10.1002/elps.1150170213

[12] Wang, L., Goh, B., Fan, L. and Lee, H. (2004) Sensitive High-Performance Liquid Chromatography/Mass Spectrometry Method for Determination of Steviol in Rat Plasma. Rapid Communications in Mass Spectrometry, 18, 83-86. http://dx.doi.org/10.1002/rcm.1285

[13] Hearn, L. and Subedi, P. (2009) Determining Levels of Steviol Glycosides in the Leaves of Stevia rebaudiana by Near Infrared Reflectance Spectroscopy. Journal of Food Composition and Analysis, 22, 165-168. http://dx.doi.org/10.1016/j.jfca.2008.10.008

[14] Bergs, D., Burghoff, B., Joehnck, M., Martin, G. and Schembecker, G. (2012) Fast and Isocratic HPLC-Method for Steviol Glycosides Analysis from Stevia rebaudiana Leaves. Journal für Verbraucherschutz und Lebensmittelsicherheit, 7, 147-154. http://dx.doi.org/10.1007/s00003-012-0760-5

[15] Gardana, C., Scaglianti, M. and Simonetti, P. (2010) Evaluation of Steviol and Its Glycosides in Stevia rebaudiana Leaves and Commercial Sweetener by Ultra-High-Performance Liquid Chromatography-Mass Spectrometry. Journal of Chromatography A, 1217, 1463-1470. http://dx.doi.org/10.1016/j.chroma.2009.12.036

[16] Hashimoto, Y., Moriyasu, M., Nakamura, S., Ishiguro, S. and Komuro, M. (1978) High Performance Liquid Chromatographic Determination of Stevia Components on a Hydrophilic Packed Column. Journal of Chromatography A, 161, 403-405. http://dx.doi.org/10.1016/S0021-9673(01)85262-6

[17] Kolb, N., Herrera, J.L., Ferreyra, D.J. and Uliana, R.F. (2001) Analysis of Sweet Diterpene Glycosides from Stevia rebaudiana: Improved HPLC Method. Journal of Agricultural and Food Chemistry, 49, 4538-4541. http://dx.doi.org/10.1021/jf010475p

[18] Tada, A., Ishozuki, K., Iwamura, J., Mikami, H., Hirao, Y., Fujita, I., Yamazaki, T., Akiyama, H. and Kawamura, Y. (2013) Improvement of the Assay Method for Steviol Glycosides in the JECFA Specification. American Journal of Analytical Chemistry, 4, 190-196. http://dx.doi.org/10.4236/ajac.2013.44024

[19] Chester, K., Tamboli, E., Singh, M. and Ahmad, S. (2012) Simultaneous Quantification of Stevioside and Rebaudioside A in Different Samples Collected from the Indian Subcontinent. Journal of Pharmacy and Bioallied Sciences, 4, 276-281. http://dx.doi.org/10.4103/0975-7406.103236

[20] Jaitak, V., Gupta, A.P., Kaul, V.K. and Ahuja, P.S. (2008) Validated High-Performance Thin-Layer Chromatography Method for Steviol Glycosides in Stevia rebaudiana. Journal of Pharmaceutical and Biomedical Analysis, 47, 790-794. http://dx.doi.org/10.1016/j.jpba.2008.03.022

[21] Londhe, S.V. and Nanaware, S.M. (2013) HPTLC Method for Simultaneous Analysis of Stevioside and Rebaudioside-A in Stevia rebaudiana. Journal of AOAC International, 96, 24-26. http://dx.doi.org/10.5740/jaoacint.11-257

[22] JECFA (2010) Steviol Glycosides, FAO JECFA Monographs. FAO, Rome.

[23] ICH (2005) Harmonized Tripartite Guideline Validation on Analytical Procedures: Text and Methodology. International Conference on Harmonization Q2(R1), Genova, November 2005, 8-13.

[24] Jaworska, K., Krynitsky, A.J. and Rader, J.I. (2012) Simultaneous Analysis of Steviol and Steviol Glycosides by Liquid Chromatography with Ultraviolet Detection on a Mixed-Mode Column: Application to Stevia Plant Material and Stevia-Containing Dietary Supplements. Journal of AOAC International, 95, 1588-1596. http://dx.doi.org/10.5740/jaoacint.11-435

[25] Wöelwer-Rieck, U. (2012) The Leaves of Stevia rebaudiana (Bertoni), Their Constituents and the Analyses Thereof: A Review. Journal of Agricultural and Food Chemistry, 60, 886-895. http://dx.doi.org/10.1021/jf2044907

[26] Jarma-Orozco, A., Araméndiz-Tatis, H. and Cleves-Leguízamo, A. (2011) Phenotypic Stability and Plant Densities of Stevia (Stevia rebaudiana Bert.) Genotypes in the Caribbean Region of Colombia. Acta Agronómica, 60, 165-175. 
Scientific Research Publishing (SCIRP) is one of the largest Open Access journal publishers. It is currently publishing more than 200 open access, online, peer-reviewed journals covering a wide range of academic disciplines. SCIRP serves the worldwide academic communities and contributes to the progress and application of science with its publication.

Other selected journals from SCIRP are listed as below. Submit your manuscript to us via either submit@scirp.org or Online Submission Portal.
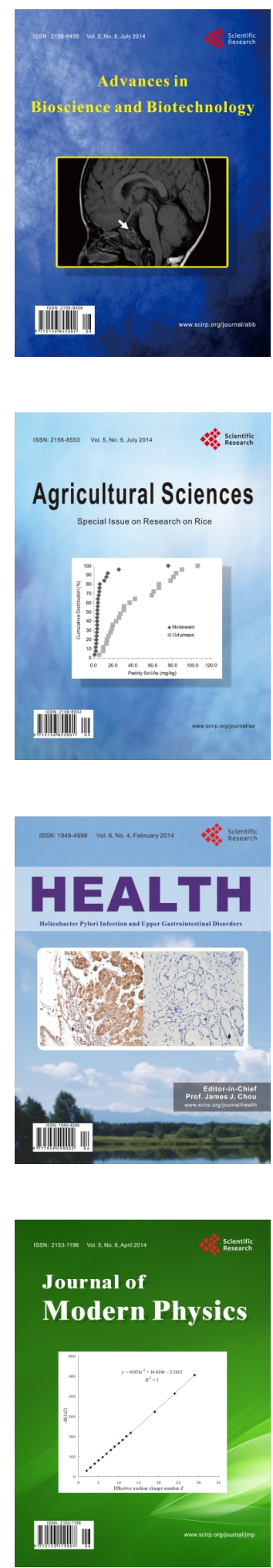
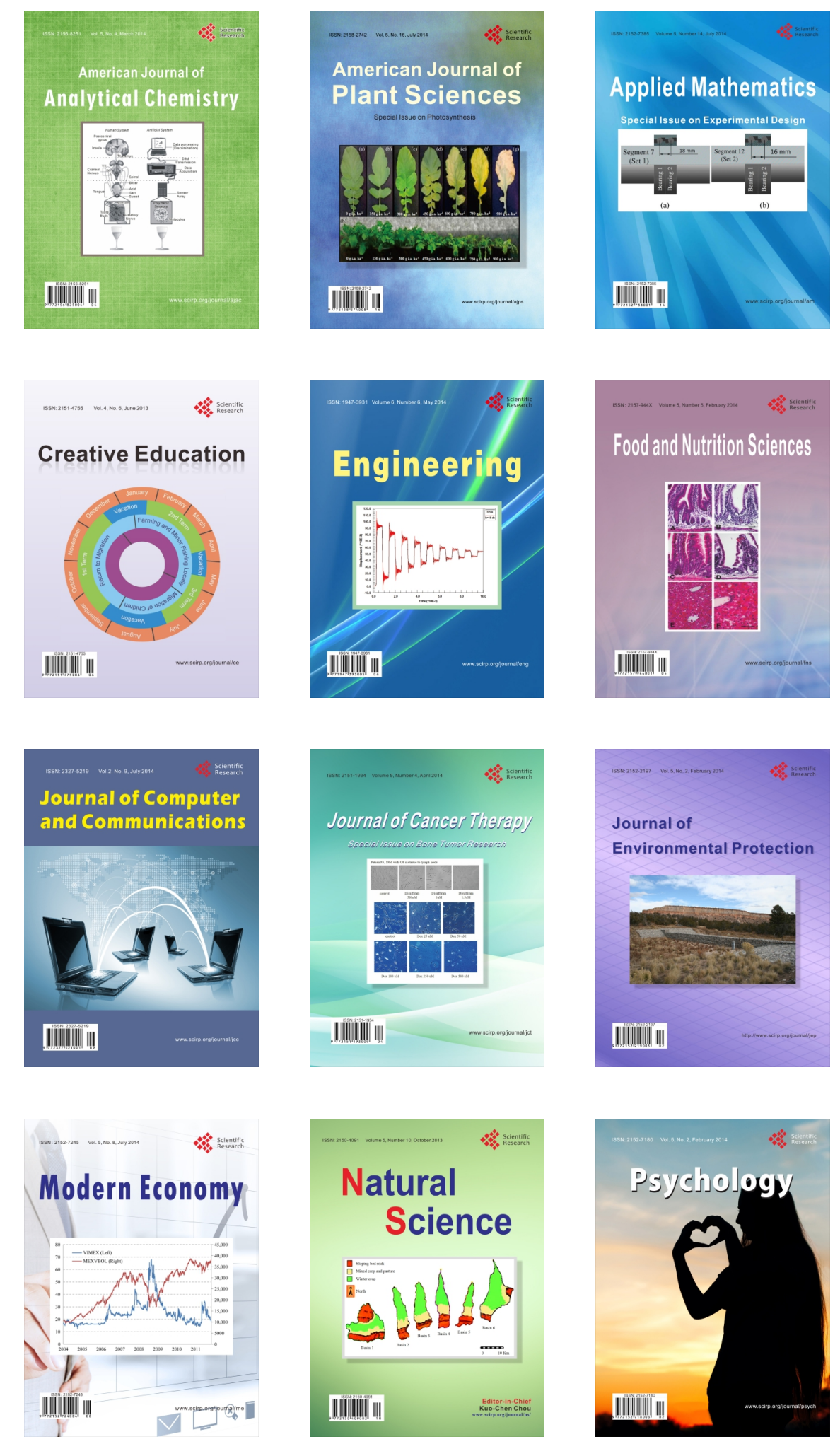